\title{
IDENTIFICATION OF BIOMASS MAJOR CRITERIA. CASE OF THE STUDY, IRAN CELLULOSE MATERIAL
}

\author{
Majid Azizi* \\ Associate professor, Faculty of Natural Resources \\ University of Tehran, \\ Email: mazizi@ut.ac.ir \\ Fatemeh Rahimi \\ Graduate MS student, Faculty of Natural Resources \\ University of Tehran
}

\begin{abstract}
Energy is the most basic material demand for human existence and development. Energy consumption level is used as the criteria to indicate the economic and social development level of a certain region. Energy consumption will continue to be the main sources of energy over the next few decades, in spite of concerns about climate change, energy security and the efforts of several countries to develop alternatives. Biomass is an important source for energy generation in several developing countries. Biomass's abundance, renew ability, versatility, and carbon-neutrality make it well suited as a feedstock for energy applications, and as an alternatives to fossil fuels. Biomass (forest residues, Agricultural waste and wood) can be used to produce thermal energy, electricity, and transportation fuels. In AHP the goal is study of criteria identification for production of renewable energy from cellulose materials, and the scale is benefits, costs, opportunities and risks. After pair wise comparison was made for sub criteria of BOCR, the highest criteria under each of the merits have been found.
\end{abstract}

Keywords: AHP, Biomass, cellulose material, energy

\section{Introduction}

Biomass is a kind of energy which is produced from photosynthesis performance and is the most suitable renewable energy resources, in addition to, is advocate of environment and the most utilizable energy which has been considered by man in the past years (Hsu et al, 1980).

In last three decade world energy needs has increased rapidly. World energy consumption was 3.3 Giga ton in 1930 and this amount increased in 8.8 Giga ton in 1960 which has had 3.3 percent growth rate annually as well as this rate will increase 13 and 14 Giga tone in years of 2010 and 2020. Hence amount of world energy consumption is high in future century and it is vital different countries especially developing countries exploit from other renewable energies (SANA, 2009).

The scientists believe need to energy is very important and effective factor in exploitation of resources and environmental changes (Kanagawa and Nakata, 2006). Level of energy consumption can be important factor to show development of human community in social and economic sections (Sayin et al, 2005). Among of various renewable energy, biomass is the fourth energy resource in the world and supply 14 percent of the world energy needs (FAO, 2004). Obtainable fuel from biomass changing is in form of gas or liquid which is used to produce electricity and heat (SANA, 2009). 31 percent of Iran soil, equivalent 51 million hectare, is good for agricultural activities whilst 64 percent of the soil resources equivalent 33 million hectare has not been exploited to produce yet.

\footnotetext{
Corresponding author
} 
Also agricultural activities are main resources to produce cellulose materials such as forest residues, agricultural waste and wood. These statistics and Iran geographic situation indicate criteria identification for production of renewable energy from cellulose materials is necessary to supply energy in the country.

\section{Analytic Hierarchy Process}

One of the best weighting methods approaches for this case is the analytic hierarchy process (AHP). The AHP for decision making is a theory of relative measurement based on paired comparisons used to derive normalized absolute scales of numbers whose elements are then used as priorities (Saaty, 1980 and 2000). To perform of the research after preparing the questionnaires, 13 experts from industries, environment, wood industries, agriculture, forests and internal \& external academic members have been selected, distributed and received. After collecting merits of benefits, opportunities, costs and risks regard to renewable energy from cellulose materials the results were synthesized and analyzed by Expert Choice software.

\section{BOCR structure}

\section{The indexes related to Benefits}

The favorite certain indexes said benefit that certainly in coming future receive the result of it. On the other hand, this results discover positive effects and to be reckoned advantage.

\section{Create a job}

1-1.Increased appeal native skilled workforce

Because of decrease available cost in factory, the mainly workforce of special area, because of employment to take into employ in productive unit.

1-2. Increased native income

Increased employment, improvement new economic, increased farmer's income \& etc included increased native income.

2. Raw material

\section{2-1.Expand farming field}

Because of top needs of raw material in factories, the necessity expands wood farming \& plantation of rapid trees \& also agriculture products, because of supply raw material of needing factories.

\section{2-1-1.Increased wood farming}

Wood farming as one of the supply resources of raw material can discharge important role in decrease pressure over on natural resource \& supply raw material in industry.

2-1-2.Expand the plantation agriculture product

Because of expand of agriculture fields \& the top of volume wastage like straw, wheat, rice, maize stem, bagasse cane sugar, etc can use for supply energy.

\section{2-2.The Use of outputs of low value forests}

\section{2-2-1. Clearance of forest filed}

With wastage exit resulting as operation of cut \& exploitation forest trees like: bark, timber, branches small \& low - set, death trees, etc can compensate part of raw material.

\section{2-2-2. Increased sales of low value woods}

The selling of section of woods with a view to qualitative settle in low class, do not use in special industries. 


\section{2-3.Increased factories income of wood industries}

\section{2-3-1. Sales residues}

With selling waste like saw dust, shaving, etc as a raw material to energy generation factories create additional income for factory.

2-3-2. decrease the cost of waste disposal

With selling waste, to prevent the cost of destruction \& burning waste.

\section{Infrastructure}

To create an infrastructure like transportation, energy, connection, needing water in farming \& etc to pay attention with factory needing to accelerate in consideration area.

\section{Financier}

To create database of raw material financier that include wood industrials mills, farming wood \& forests situation \& farming fields.

\section{4-1. waste}

4-1-1.The waste of wood industrials mills

The waste of wood industrials mills receive as a raw material financier resource.

\section{4-1-2.farming wastage}

Farming waste to supply as an energy financier resource with very top potential in country.

\section{4-2. Amounts of trees resulting as farming wood}

To estimate amount of under plantation land, this kind of trees \& recognize farmers to Plant this kind of trees.

\section{4-3.forest position}

To determinate a mount of annual remove to take, because of using forest trees waste $\&$ energy financier raw material factories.

\section{The indexes related to Costs}

An undesired certain indexes said cost, that certainly in coming future receive the result of it. On the other hand, this results discover negative effects and to be reckoned dangerous.

\section{Economical}

\section{1-1.Cost of land}

The cost average of square metere lands in area that expense for using industry or established factory.

\section{1-2. Cost of transportation}

This expense include raw material transportation of presentation \& order like (forest, wood industrials mills, farming wood \& farming land) to productive unit.

1-3. the cost of forest road construction

Farming land.

Says, the expenses for construction forest road, as waste output $\&$ waste cut trees $\&$

1-4. Operation cost

1-4-1.Cost of manpower 
Include salary, wage and other cost of life, like (cost of house, hygiene, food \& welfare) business man in producing unit.

\section{1-4-2. Cost of buying raw material}

Included expenses like: cost of buying forest waste, waste of farming land, the wood that cut of rapid plant trees $\&$ waste of wood industrial mills of supply resources $\&$ presentation for producing specific material.

\section{Social \& cultural}

To create a worried in public mind, soc iety, wood industries financier \& environment partisans, in the mean time energy producing of wood \& cellulose materials, that resulting as to take a specific plans.

\section{The indexes related to opportunities}

The favorite certain indexes said opportunities, that probably in coming future receive the result of it. On the other hand, this results discover positive effects and to be reckoned advantage.

\section{Development}

\section{1-1. Local economy}

Depends on area of established factory, area economic increased with matters like create job, farming field \& increased income of farmers.

1-2. Development the wood industrial mills

By resulting this point, one of the supply raw material resources is wastage wood industry factories. It depends on area of established supply energy factory \& concentration of wood industrial mills s increased in area. So that to observe decreased in amount of transportation.

\section{1-3. farming field}

Because of knowing related method with: using farming waste in producing energy \& product of under plant field.

2. The sale \& production of heat, electric ity \& fuel

Because of positive point cellulose material that differences as compared with another renewable energy, to make prepare the sale \& production of heat, electricity \& fuel, that to prove factory development \& entrance new machine.

\section{Future investment}

Area capability with a view to absorb investment or local possibilities in area that investment interested in starting special activity in the future.

4. Improve the management forest system

With improving management system in sustainable development forest resources \& supervisory system in future can being effective step in supplying suitable raw material in industry \& decrease destroy forest resources.

\section{Increased government support}

5-1. giving facilities (foreign exchange \& rail)

Include: easiness, rapid \& volume giving bank facilities

\section{5-2. exemption taxes}

Exemption taxes included special industry activities like exemption taxes taking in first 
operation.

\section{The indexes related to risks}

An undesired certain indexes said risk, that probably in coming future receive the result of it. On the other hand, this results discover negative effects and to be reckoned dangerous.

1. Unsure of constant raw material supply

Demand for raw material like (trees production system short rotation, forest waste $\&$ farming waste) because of starting new units increased, so do not have sure for demand raw material in future.

2. Create problem from government $\&$ associated organization

2-1. Lack of financial supporter

To have doubt in receive \& supply financial resources in amount \& predict time that starting factory activity to deal with many problems.

\section{2-2. Non constancy government rules}

Not passing prediction laws in factory establish \& change in them that starting factory activity to deal with many problems.

\section{2-2-1. Tax rules}

Change of Tax rules enact $\&$ increased them of established time.

\section{2-2-2. decrease amount of law using forest resources}

To change in amount of law using forest resources \& other connected organization that starting factory activity to deal with new problems.

\section{Environmental problems}

\section{3-1. Decrease of fields using}

Changing using fields of the form food producing to producing environ fuel, because of increased farmer's income that takes effect on local food situation.

\section{3-2. Change in forest management regimes}

To change soil nutrients, decrease in biodiversity \& soil erosion that appearance with entrance wastage of forest.

\section{3-3. Damage the forest}

Lack of attention ecosystem forests situation \& using transient management situation in background of forest resources that accompanied by deforestation $\&$ decrease value of it.

\section{Results}

Table 1: Final outcome regard to benefits (Inconsistency ratio: 0.03)

\begin{tabular}{|l|l|}
\hline Main criteria & $\begin{array}{l}\text { Weighing } \\
\text { value }\end{array}$ \\
\hline $\begin{array}{l}\text { Agricultural } \\
\text { products }\end{array}$ & 0.245 \\
\hline Wood farming & 0.124 \\
\hline Native income & 0.113 \\
\hline Clearance & 0.099 \\
\hline Infrastructure & 0.061 \\
\hline Skilled workforce & 0.051 \\
\hline Low value woods & 0.050 \\
\hline Disposal waste & 0.050 \\
\hline
\end{tabular}

Table 2: Final outcome regard to costs (Inconsistency ratio: 0.04)

\begin{tabular}{|l|l|}
\hline Main criteria & $\begin{array}{l}\text { Weighing } \\
\text { value }\end{array}$ \\
\hline Social \& cultural & 0.338 \\
\hline Transportation costs & 0.337 \\
\hline Cost of buy ing raw material & 0.162 \\
\hline Cost of land & 0.067 \\
\hline Cost of man power & 0.051 \\
\hline Cost of forest road construction & 0.045 \\
\hline
\end{tabular}




\begin{tabular}{|l|l|}
\hline Farming waste & 0.039 \\
\hline Sales residues & 0.034 \\
\hline Amounts of trees & 0.025 \\
\hline Wood industrials & 0.018 \\
\hline Forest position & 0.013 \\
\hline
\end{tabular}

Table 3: Final outcome regard to opportunities (Inconsistency ratio: 0.02)

\begin{tabular}{|l|l|}
\hline Main criteria & $\begin{array}{l}\text { Weighing } \\
\text { value }\end{array}$ \\
\hline Local economy & 0.293 \\
\hline Sale and production & 0.234 \\
\hline Future investment & 0.127 \\
\hline Faming field & 0.124 \\
\hline Exemption taxes & 0.067 \\
\hline $\begin{array}{l}\text { Improvement of } \\
\text { management forest } \\
\text { system }\end{array}$ & 0.055 \\
\hline $\begin{array}{l}\text { Development of } \\
\text { wood industries } \\
\text { factories }\end{array}$ & 0.051 \\
\hline Giving facilities & 0.047 \\
\hline
\end{tabular}

Table 4: Final outcome regard to risks (Inconsistency ratio: 0.01)

\begin{tabular}{|l|l|}
\hline Main criteria & $\begin{array}{l}\text { Weighing } \\
\text { value }\end{array}$ \\
\hline $\begin{array}{l}\text { Unsure of constant } \\
\text { raw material supply }\end{array}$ & 0.645 \\
\hline $\begin{array}{l}\text { Lack of fin ancial } \\
\text { support }\end{array}$ & 0.153 \\
\hline Tax rules & 0.065 \\
\hline $\begin{array}{l}\text { Decrease of fields } \\
\text { using }\end{array}$ & 0.058 \\
\hline $\begin{array}{l}\text { Changing in forest } \\
\text { management } \\
\text { regimes }\end{array}$ & 0.039 \\
\hline $\begin{array}{l}\text { Decrease forest } \\
\text { resources }\end{array}$ & 0.022 \\
\hline Damage the forest & 0.018 \\
\hline
\end{tabular}

\section{Discussion and conclusion}

Analysis of benefits: in the most of producer industries of energy as well as in this research, raw material criteria have the highest priority. Existence of enough, sustainable and cheap raw material is vital to establish producer factories of energy. Wastes of agricultural lands, wood farming, woods of forests and wastes of wood industries factories are main resources which are utilized them to produce energy. Approximately half of population in the world utilizes biomass resources to supply energy needs. Synthesizing benefits criteria indicated agricultural products $(0.245)$ has the highest priority. These products are the main resources of new energy in other countries and have a key role to produce energy (Mahdavi, 2001). In Euro countries and United States of America, agricultural wastes are applied to produce energy such as Ethanol and methanol (Plieninger et al 2009).

Analysis of costs: regard to overall synthesizing social and cultural criterion (0.338) has the highest priority. With based on investigations of UN-Energy (2007) exploitation of agricultural wastes and forest residues cause to decrease of nitrate absorption and extraction of forest residues give rise to soil erosion and decrease of soil fertility. Main while growth of the trees depends on nitrate absorption. Therefore, giving scientific solutions from researchers and scientists to decrease of pressure on the lands will have important role in reduction of the anxiety.

Analysis of opportunities: local economy criterion (0.293) has the highest priority according to opportunities. Study of website of Dovetail depend on America renewable energies organization (2009) in challenges and benefits of biomass utilization presented resources district of biomass are protected in local area, practically, as a result transfer of residual and wastes is economical, in the case of, economical radius is considered. Economical radius in United States is 50 mile or less for transferring cutting residual and 70 mile respect to wood and agricultural wastes transfer. Hence, it will be possible, both increasing local income and reduction of wood wastes firing and evacuation costs through exploitation of forests wastes and low quality woods. Besides, employment of local man force for cutting, harvest, transportation, chipping and fuel transfer are carried out by utilizing accessible biomass resources which is provided from local resources owners, and likewise in local community energy occupations are generated, similarly increasing economic activities, local economy development and increasing agricultural products will be acquired. 
Analysis of risks: Regard to risks, unsure of constant raw material supply criterion (0.645) has the highest priority. Wyman (2003) believe the most important factor on activities continuation of energy producer's factories is raw material supply in high volume and continuously. In addition to Coleman et al (2006) refers the most effective factor in beginning and permanence of the factories is having enough and appropriate raw material.

\section{REFERENCES}

Coleman M, Stanturf J., 2006, Biomass feedstock production systems: economic and environmental benefits, Biomass and Bio energy, 30, 693-5

Hsu T. A., Ladisch M.R. and Tsao G.T., 1980, Alcohol from cellulose, Chemtech May, pp. 315-139

Kanagawa M., Nakata T. 2006, Analysis of the energy access improvement and its socio-economic impacts in rural areas of developing countries. Ecological Economical, 58(1), 1-11

Mahdavi H., 2001, Investigation and feasibility study of material production from agricultural wastes and changeable industries, first conference of prevention from dissipation of national resources

Plieninger T., Thiel A., Bens O., 2009, Pathways and pitfalls of implementing the use of wood fuels in Germany' bio energy sector biomass and bio energy, 33, 384-392

Saaty, T.L., 1980, the analytic Hierarchy Process", McGraw-Hill international. New York, RWS publications, Pittsburgh

Saaty, T.L., 2000, Fundamentals of Decision Making with Analytic Hierarchy Process", paperback, RWS publications, 4922 Ellsworth Avenue, Pittsburgh, PA 15213-2807

SANA, 2009, Development of new energies in the country, journal of organization of Iran new energies

Sayin C., Mencet M., Ozkan B., 2005, Assessing of energy polices based on Turkish agriculture: Current status and some implications, Energy Policy, 33(18), 2361-73

UN- Energy, 2007, Sustainable bio energy: a framework for decision-makers, New York

Www. Faostat.fao.org

Www.dovetaillinc.org

Wyman C., 2003, Potential synergies and challenges in refining cellulose biomass to fuels, chemicals and power, Biotechnology Progress, 19, 254-62 